\title{
Original paper \\ Indium-bearing paragenesis from the Nueva Esperanza and Restauradora veins, Capillitas mine, Argentina
}

\author{
María Florencia MÁRQUEZ-ZAVALÍA ${ }^{1,2^{*}}$, Anna VYMAZALOVÁa ${ }^{3}$, Miguel Ángel GALLISKI", \\ Yasushi WATANABE ${ }^{4}$, Hiroyasu MURAKAMI ${ }^{5}$
}

\author{
${ }^{\prime}$ IANIGLA, CCT-Mendoza (CONICET), Avda. A. Ruiz Leal s/n, Parque San Martin, CC330, (5500) Mendoza, Argentina; \\ mzavalia@mendoza-conicet.gov.ar \\ ${ }^{2}$ Mineralogía y Petrología, FAD, Universidad Nacional de Cuyo, Centro Universitario (5502) Mendoza, Argentina \\ ${ }^{3}$ Department of Rock Geochemistry, Czech Geological Survey, Geologická 6, 15200 Prague 5, Czech Republic \\ ${ }^{4}$ Faculty of International Resource Sciences, Mining Museum of Akita University, 28-2 Osawa, Tegata, Akita, 010-8502 Japan \\ ${ }^{5}$ Coal Business Planning Group, Coal Business Office, Resources \& Power Company, JXTG Nippon Oil \& Energy Corporation, \\ 1-2, Otemachi 1-chome, Chiyoda-ku, Tokyo 100-8162 Japan \\ * Corresponding author
}

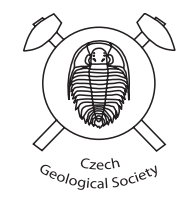

\begin{abstract}
The Nueva Esperanza and Restauradora are two of the twenty-three veins described at Capillitas mine, an epithermal precious- and base-metal vein deposit located in northern Argentina. Capillitas is genetically linked to other mineralizations of the Farallón Negro Volcanic Complex, which hosts several deposits. These include two world-class (La Alumbrera and Agua Rica) and some smaller (e.g., Bajo El Durazno) porphyry deposits, and a few epithermal deposits (Farallón Negro, Alto de la Blenda, Cerro Atajo and Capillitas). The main hypogene minerals found at these two veins include pyrite, sphalerite, galena, chalcopyrite, tennantite-(Zn) and tennantite-(Fe). Accessory minerals comprise hübnerite, gold, silver, stannite, stannoidite and mawsonite, and also diverse indium- and tellurium-bearing minerals. Quartz is the main gangue mineral.

Indium participates in the structure of sphalerite, tennantite-(Zn), ishiharaite and an indium-bearing mineral, still under study, the former being the most abundant of these phases. The chemical composition of sphalerite shows very low concentrations of $\mathrm{Fe}$ and a wide range in indium contents from below the detection limit $(0.03 \mathrm{wt} . \%)$ to values close to 22 wt. \%. Atomic proportions of In and $\mathrm{Cu}$ correlate positively at a ratio $\mathrm{In}: \mathrm{Cu}=1: 1$ atoms per formula unit. Cadmium reaches up to 0.68 wt. \%. Other analyzed elements ( $\mathrm{Ge}, \mathrm{As}, \mathrm{Se}, \mathrm{Ag}, \mathrm{Sn}, \mathrm{Te}, \mathrm{Au}, \mathrm{Pb}$ and $\mathrm{Bi}$ ) are systematically below their respective detection limits. Indium-bearing tennantite-( $\mathrm{Zn}$ ) (up to $0.24 \mathrm{wt}$. \% In) is rare and restricted to the area where ishiharaite appears. Ishiharaite and the unclassified indium-bearing mineral are extremely scarce and host up to 10 and $30 \mathrm{wt}$ \% In, respectively.

The zoning in sphalerite and the variable indium content of the different bands could be ascribed to significant fluctuation in the composition of the fluids (possibly pulses). They are evidenced by the presence of a high $f \mathrm{Te}_{2}$ mineral, like calaverite, and a low $f \mathrm{Te}_{2}$ phase, such as silver, within the same stage, with local periodic increments on In and $\mathrm{Cu}$ that could also be associated with recurring reactivation of fractures.
\end{abstract}

Keywords: Indium-bearing minerals, ishiharaite, sphalerite, epithermal, Farallón Negro Volcanic Complex, Argentina Received: 20 January 2020; accepted: 3 May 2020; handling editor: J. Zachariáś

\section{Introduction}

The Capillitas mine is an intermediate sulfidation epithermal precious- and base-metal vein deposit in northern Argentina (Márquez-Zavalía 1988, 1999; Putz et al. 2009). It is genetically linked to the other mineralizations of the Farallón Negro Volcanic Complex (MárquezZavalía and Heinrich 2016, and references therein). This complex hosts two world-class porphyry deposits, namely La Alumbrera and Agua Rica, some smaller deposits such as Bajo El Durazno and a few epithermal deposits, including Farallón Negro, Alto de la Blenda, Cerro Atajo, and Capillitas.
Capillitas is well-known not only for its banded rhodochrosite, but also for its mineralogical diversity. It hosts more than 100 identified mineral species and is the type locality of five minerals: putzite (Paar et al. 2004), catamarcaite (Putz et al. 2006), ishiharaite (Márquez-Zavalía et al. 2014), lislkirchnerite (Effenberger et al. 2015), and omariniite (Bindi et al. 2017).

During a revision of the ore-mineral samples, it was found that some minerals are enriched in indium, including ishiharaite and a potential new mineral, still under study. The findings encouraged us to perform deeper research on the subject, and the results are provided in this paper. 


\section{Indium: geochemistry, mineralogy and uses}

Indium was discovered by Reich and Richter (1863a, b) in sphalerite samples from the Freiberg district, Germany. It is estimated that the abundance of indium in the Earth's continental crust is $0.05 \mathrm{ppm}$, in the oceanic crust 0.072 ppm (Taylor and McLennan 1985, in Schwarz-Schampera and Herzig 2002), and in CI chondrites 0.08 ppm (Anders and Grevesse 1989). This element is most frequently present as substituent in the structures of several minerals (e.g., sphalerite, chalcopyrite, cassiterite), replacing the elements of similar atomic radii (e.g., $\mathrm{Zn}, \mathrm{Cu}, \mathrm{Sn}$ ). Moreover, 14 valid mineral species contain essential indium: abramovite, cadmoindite, damiaoite, dzhalindite, indite, indium, ishiharaite, laforêtite, petrukite, roquesite, sakuraiite, yanomamite, yixunite and znamenskyite. Indium, roquesite, and, to a lesser extent, dzhalindite, petrukite and sakuraiite are the most widespread; the others were reported only from one or two localities.

Indium is a highly sought element for its extensive demand in forefront technologies. During the last decade, the consumption grew at about $10 \%$ per year for varied applications, e.g., liquid crystal displays (LCD), highdefinition televisions, semiconductor materials, batteries, low-temperature solders, cell phones, touch screens, solar panels, light- and laser-emitting diodes (LED) or glass coating and nuclear medicine (Schwarz-Schampera and Herzig 2002; Royal Society of Chemistry 2020).

During the last three decades, the world's annual indium production grew, on average, from 140 to $600 \mathrm{t}$. Most of the indium is obtained as by-product from zinc smelting of sphalerite, even though the recycling industry is increasing (Goonan 2012).

\section{Indium resources in Argentina}

In Argentina, reports on indium enrichment in ore deposits are very scarce. Indium has been described only from six areas. The first description of indium in an Argentinean deposit was from Pirquitas, northwestern Argentina (Paar et al. 1998), dealing with sphalerite hosting petrukite and sakuraiite. The second find was mentioned by Zappettini et al. (2004), who described sphalerite from quartz veinlets of El Peladar prospect, Jujuy, with indium contents up to $0.29 \mathrm{wt}$. \%. A short time later, Márquez-Zavalía (2005) mentioned an indium-bearing paragenesis from the Restauradora vein, in Capillitas, northwestern Argentina. Sphalerite, with contents of indium over $20 \mathrm{wt} . \%$, is accompanied by two indium minerals: ishiharaite (Márquez-Zavalía et al. 2014), and a potential new mineral, still under study. The same year, Guido et al. (2005) reported the presence of indium in the Deseado Auroargentiferous Province (Schalamuk et al. 1999), Deseado Massif, Patagonia, with an average content of $9.02 \mathrm{ppm}$ of In for the Cerro León prospect. Further studies in the Deseado Province focused on the Pingüino vein system concluded that indium is mainly concentrated in Fe-rich sphalerite and, to a lesser extent, in ferrokësterite and greenockite (Jovic et al. 2009, 2011, 2015). The fifth occurrence was reported from the San Roque prospect, Macizo Nordpatagónico, by Gómez et al. (2008). They described the presence of sphalerite with indium contents up to $0.12 \mathrm{wt}$. \%. Last, Gallard-Esquivel et al. (2018) described the occurrence in two prospects from La Carolina district, San Luis. They reported on sphalerite with contents of indium ranging from 0.01 to 0.19 wt. $\%$, and gave two analyses of the higher concentrations ( 0.36 and 0.59 wt. \%). These authors pointed out that the highest analyzed indium contents corresponded to Fe-poor sphalerite.

To sum up, the indium exploration in Argentina should be encouraged and the zinc deposits re-studied since the presence of indium in them may have been overlooked.

\section{Analytical methods}

Fieldwork at Capillitas was conducted during several field trips. Samples were collected from all veins of the deposit, both underground, as well as from outcrops and dumps.

Microscopic examinations of ore minerals were undertaken on 29 polished thin-sections and 350 standard polished sections. All the polished thin-sections and 21 from the standard polished sections correspond to the Nueva Esperanza and Restauradora veins. These examinations were undertaken under a reflected-light polarizing microscope, before carbon-coating for electron-microprobe analyses (EPMA) took place.

A total of 53 chemical point analyses were obtained using a Cameca SX-50 electron microprobe at the Department of Geological Sciences, University of Manitoba, Winnipeg, Canada. The analytical conditions were: an accelerating voltage of $15 \mathrm{kV}$, a beam current of $20 \mathrm{nA}$ measured on a Faraday cup, a counting time of $20 \mathrm{~s}$ for each element, and $10 \mathrm{~s}$ for the background, with a beam diameter of $2 \mu \mathrm{m}$. The standards and analytical lines selected were as follows: $\mathrm{S}, \mathrm{Cu}, \mathrm{Fe}\left(\mathrm{CuFeS}_{2}, K_{\alpha}\right), \mathrm{Mn}$ $\left[\mathrm{Mn}_{3} \mathrm{Al}_{2}\left(\mathrm{SiO}_{4}\right)_{3}, K \alpha\right], \mathrm{Ni}\left(\mathrm{Ni}_{9} \mathrm{~S}_{8}, K_{\alpha}\right), \mathrm{Zn}\left(\mathrm{ZnS}, K_{\alpha}\right), \mathrm{Ga}$ $\left(\mathrm{GaAs}, K_{\alpha}\right), \mathrm{Au}\left(\mathrm{Au}_{100}, M_{\alpha}\right), \mathrm{Ag}\left(\mathrm{Au}_{60} \mathrm{Ag}_{40}, L_{\alpha}\right)$, In, As (InAs, $\left.L_{\alpha}\right)$, Sn $\left(\mathrm{SnO}_{2}, L_{\alpha}\right), \mathrm{Sb}, \mathrm{Te}\left(\mathrm{Sb}_{2} \mathrm{Te}_{3}, L_{\alpha}\right), \mathrm{Pb}(\mathrm{PbS}$, $\left.M_{\alpha}\right)$, Bi, Se $\left(\mathrm{Bi}_{2} \mathrm{Se}_{3}, M_{\beta}, L_{\alpha}\right)$ and $\mathrm{Cd}\left(\mathrm{CdSe}, L_{\alpha}\right)$. Data were reduced using the PAP routine of Pouchou and Pichoir (1985).

Sixty-five additional analyses were obtained with a JEOL JXA-8900R electron microprobe at the National 


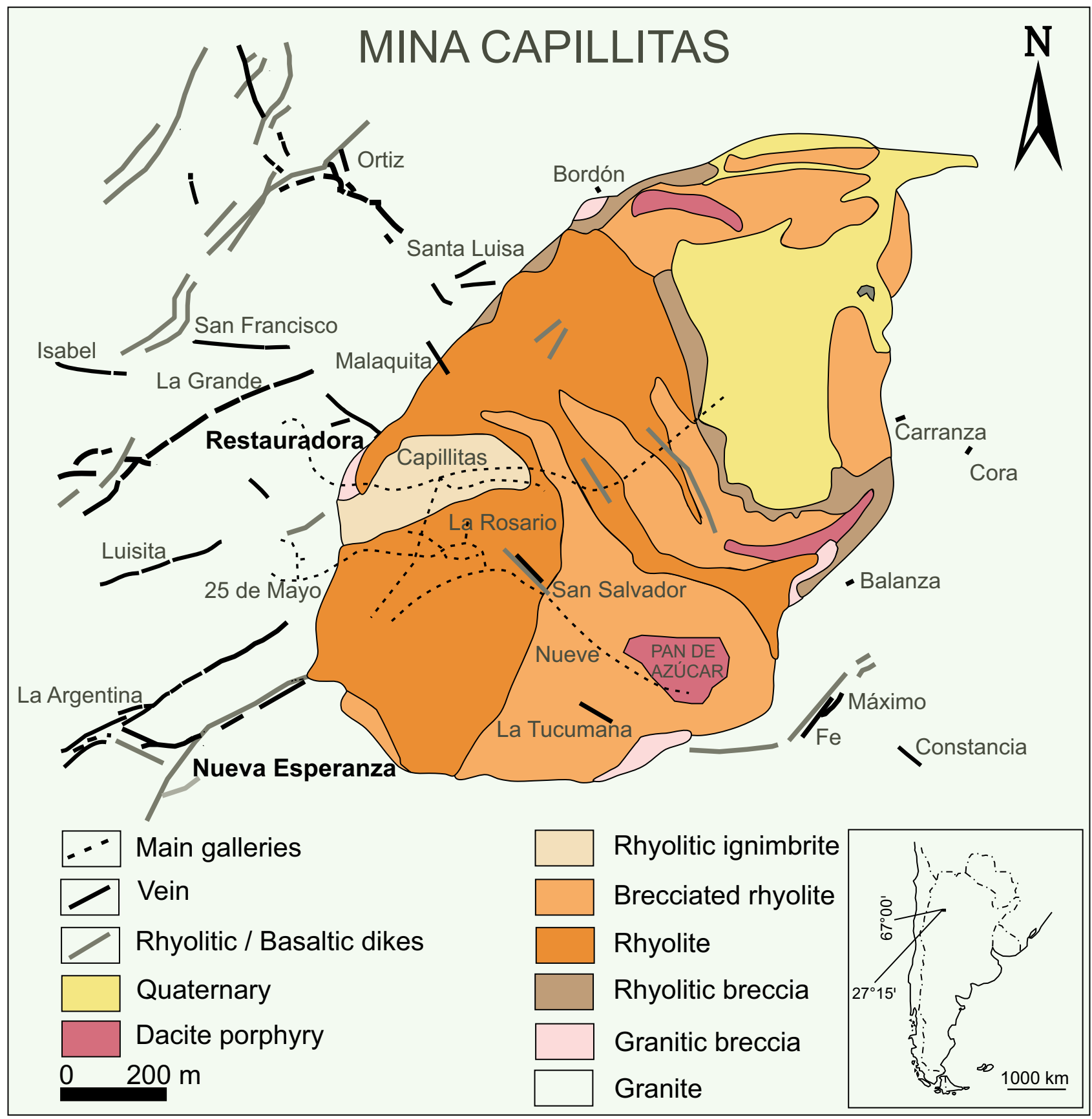

Fig. 1 Schematic geology of Capillitas, showing the location of Nueva Esperanza and Restauradora veins (modified from Márquez-Zavalía 2008).

Institute of Advanced Industrial Science and Technology (AIST), Geological Survey of Japan, Tsukuba, Japan. The equipment was operated at $15 \mathrm{kV}, 20 \mathrm{nA}$, measured on a Faraday cup, $2 \mu \mathrm{m}$ beam diameter and a counting time of $20 \mathrm{~s}$ for each element, and $10 \mathrm{~s}$ for the background. Selected standards and analytical lines are the same as in the Canadian laboratory. The ZAF method (Armstrong 1993) was employed for matrix corrections. The Canadian and Japanese routines also included Ge, As, Se, Ag, $\mathrm{Sn}, \mathrm{Te}, \mathrm{Au}, \mathrm{Pb}$, and $\mathrm{Bi}$, but all results were below their respective detection limits.

\section{Nueva Esperanza and Restauradora veins}

The Nueva Esperanza and Restauradora are two of the twenty-three veins described (Márquez-Zavalía 1988) at Capillitas mine (Fig. 1).

Nueva Esperanza vein $\left(27^{\circ} 20^{\prime} 37^{\prime \prime}\right.$ S, 66²3'24" W, 3190 $\mathrm{m}$ a.s.1.) is hosted in the Capillitas Granite. It has an approximate length of $100 \mathrm{~m}$ and a thickness of $0.30 \mathrm{~m}$, strikes $\mathrm{N} 80^{\circ} \mathrm{E}$ and dips $45^{\circ} \mathrm{S}$. Mining operations along this vein have left two exploration galleries and a shaft, 


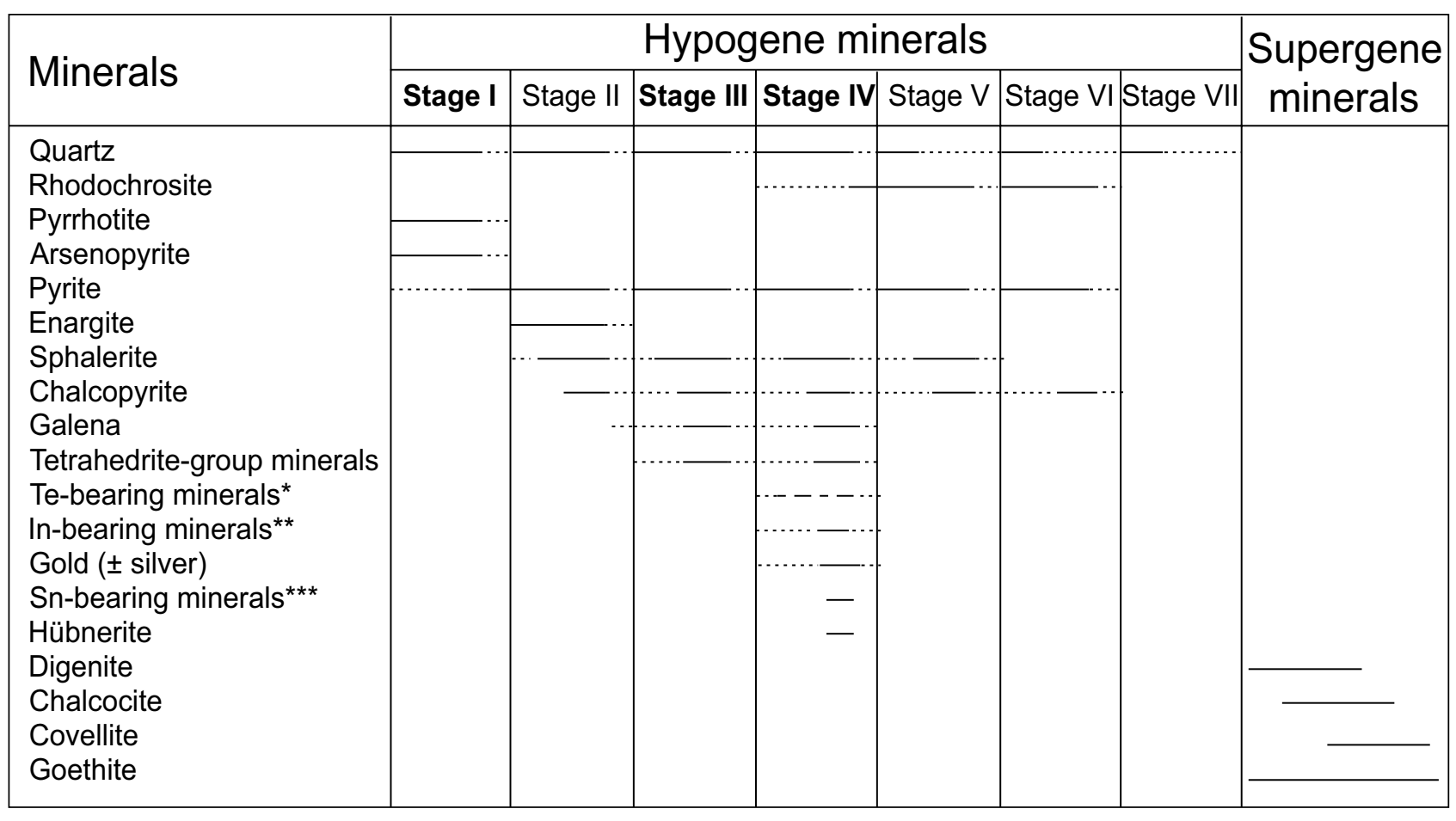

Note: Stages in bold: represented in Nueva Esperanza (I, III and IV) and Restauradora (III and IV) veins.

*: tellurium, calaverite, (goldfieldite), hessite, krennerite, melonite, petzite, stützite, sylvanite, tetradymite, and volynskite (Márquez-Zavalía and Craig 2004).

**: ishiharaite, undefined In-bearing mineral, In-bearing sphalerite, In-bearing tennantite-(Zn) (this paper).

***: mawsonite, stannite and stannoidite (Márquez-Zavalía 1988).

Fig. 2 Schematic paragenetic sequence of Capillitas deposit; Nueva Esperanza and Restauradora vein stages in bold.

with small dumps at the entrance of each gallery. One exploratory drill hole (JICA 1978-1981) cut the Nueva Esperanza vein at $372 \mathrm{~m}$ and yielded poor grades $(0.77$ $\mathrm{g} / \mathrm{t} \mathrm{Au}, 39.5 \mathrm{~g} / \mathrm{t} \mathrm{Ag}, 0.3 \% \mathrm{Cu}$ ) compared with the average grades obtained from the old galleries at surface level $(6.2 \mathrm{~g} / \mathrm{t} \mathrm{Au}, 2413 \mathrm{~g} / \mathrm{t} \mathrm{Ag}, 13.83 \% \mathrm{Cu}$ ). Three (I, III and IV) of the seven mineralization stages (Fig. 2) described for the deposit (Márquez-Zavalía 1988; Márquez-Zavalía and Craig 2004) are represented in this vein.

The Restauradora vein $\left(27^{\circ} 20^{\prime} 22^{\prime \prime} \mathrm{S}, 6^{\circ} 23^{\prime} 17^{\prime \prime} \mathrm{W}\right.$, $3190 \mathrm{~m}$ a.s.1.) is also hosted in the Capillitas Granite, has an average thickness of $50 \mathrm{~cm}$ and a total measured length of $106 \mathrm{~m}$. The vein has two branches that strike and dip $\mathrm{N} 10^{\circ} \mathrm{W} / \mathrm{N} 70^{\circ} \mathrm{E}$ and $75^{\circ} \mathrm{E}-75^{\circ} \mathrm{W} / 70^{\circ}$ $\mathrm{S}$, respectively. Mine facilities along this vein consist of a 100 meters gallery, two inclines and a shaft. There are two dumps, one over the gallery level and other below it, formed from the droppings of the one above; most of this material is oxidized. The grades reported for this vein (JICA 1978-1981) are $0.6 \mathrm{~g} / \mathrm{t} \mathrm{Au}, 209$ $\mathrm{g} / \mathrm{t} \mathrm{Ag}, 7.10 \% \mathrm{Cu}, 1.11 \% \mathrm{~Pb}, 1.49 \% \mathrm{Zn}$ and $0.07 \%$ Mn. Only two (III and IV) (Márquez-Zavalía 1988) of the seven stages of mineralization recognized in the Capillitas deposit are represented in the Restauradora vein (Fig. 2).
The main hypogene minerals that have been found in the Nueva Esperanza and Restauradora veins are pyrite, sphalerite, galena, chalcopyrite, tennantite-( $\mathrm{Zn})$ and tennantite-(Fe). Accessory minerals include hübnerite, gold, silver, indium- and tellurium-bearing minerals, stannite, stannoidite and mawsonite in a gangue mainly represented by quartz. Digenite, chalcocite, covellite, goethite, antlerite, cyanotrichite, carbonate-cyanotrichite, grandviewite, linarite, malachite and gypsum are the main supergene minerals. In general terms, during the earlier stages of mineralization crystallized quartz and pyrite ( \pm pyrrhotite and arsenopyrite), followed by sphalerite, and afterward by $\mathrm{Cu}$-bearing minerals and galena. During late stages, quartz, pyrite, sphalerite, galena and $\mathrm{Cu}$-bearing minerals continued depositing along with gold and small amounts of In-, Te-, W-, and Sn-bearing minerals (Fig. 2).

Microthermometrical data obtained from two-phase $(\mathrm{L}+\mathrm{V})$ fluid inclusions hosted in quartz of the fourth stage of the mineralization (i.e., when the indium minerals formed) gave averaged homogenization temperatures of $250^{\circ} \mathrm{C}$ and salinities of $3 \mathrm{wt} . \% \mathrm{NaCl}_{\text {equiv }}$ (MárquezZavalía 1988). This is in line with the minimum formation temperature of indium-bearing sphalerite (SchwarzSchampera and Herzig 2002; Shimizu and Morishita 2012). 

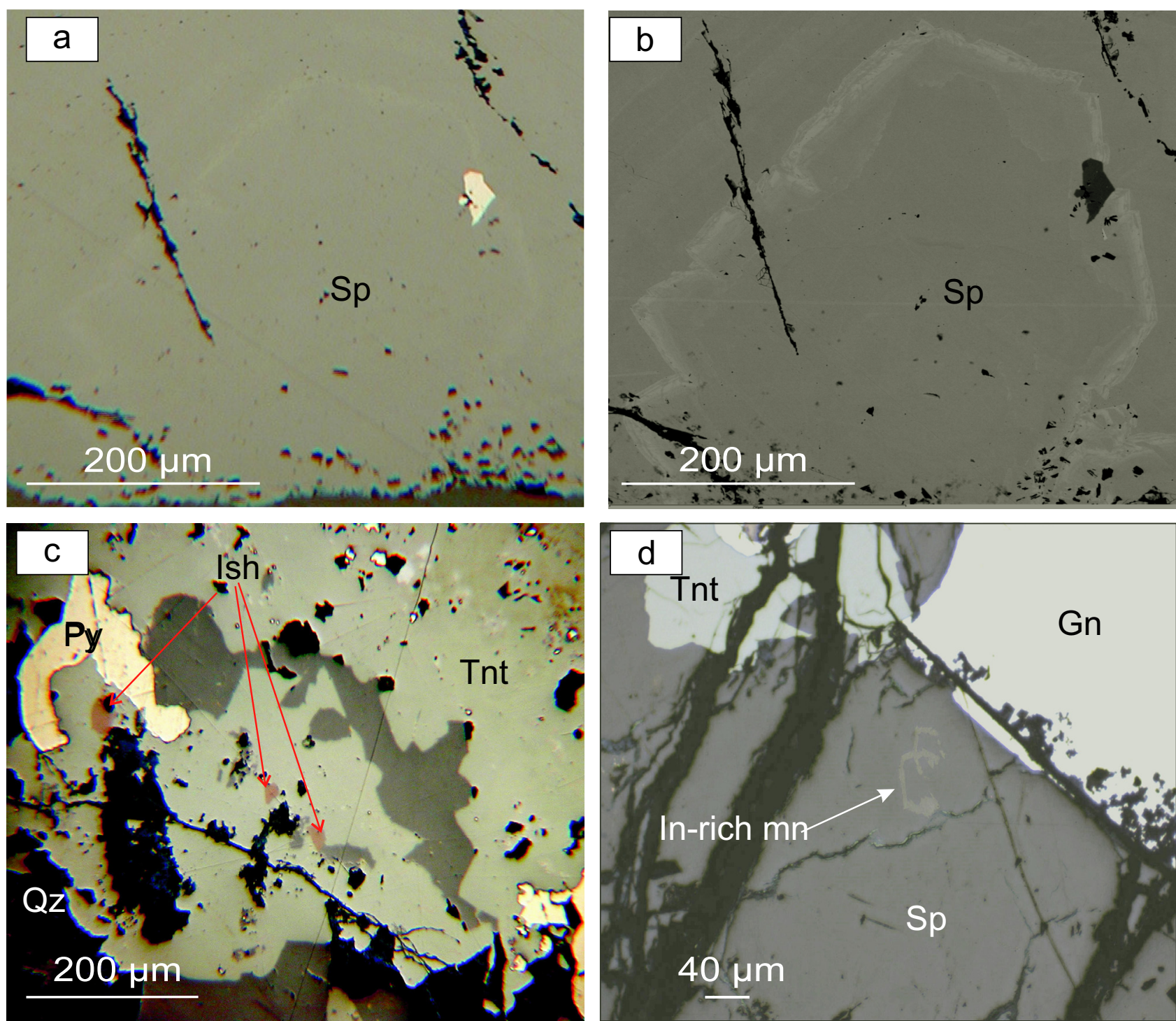

Fig. 3a Photomicrograph under the reflected-light microscope (in air) of In-bearing sphalerite (Sp) showing zonality. b - BSE image of the same. c - Reflected-light microscope photomicrograph of ishiharaite (Ish) in tennantite-(Zn) (Tnt). d - Reflected-light microscope photomicrograph of In-rich mineral in sphalerite associated with galena (Gn) and tennantite-(Zn). Abbreviations for most minerals after Whitney and Evans (2010).

\section{Mineral paragenesis of the indium minerals}

In the studied veins, indium is found to concentrate chiefly in sphalerite, tennantite-(Zn), ishiharaite and an indium-bearing mineral, potentially a new species, which is still under the study.

\subsection{Indium-bearing sphalerite}

The indium-bearing sphalerite in the Nueva Esperanza and Restauradora veins belongs to the fourth mineralization stage (Fig. 2) (Márquez-Zavalía 1988, 1999; Márquez-Zavalía et al. 2014). It can be recognized under the reflected-light microscope for its zoning (Fig. 3a-b). The bands follow a crystallographic pattern, evidenc- ing crystal growth lines and have different thicknesses, ranging from $<1$ to tens of $\mu \mathrm{m}$, (Figs 3-4). The richer in indium, the more intense the reflective power of the bands is. Increasing concentrations of indium correlate with a decreasing of the color of the mineral from medium gray, sometimes with a brown tint, to light gray in air. The other optical properties remain the same, as for normal sphalerite.

Indium content varies greatly among bands (Fig. 4a-b) along with $\mathrm{Cu}$ (Fig. 4c). Contents of In and $\mathrm{Cu}$ tend to decrease towards the rim of the crystals. Atomic proportions of $\mathrm{In}$ and $\mathrm{Cu}$ show a positive correlation with an In: $\mathrm{Cu}$ ratio close to $1: 1$.

Indium-bearing sphalerite has In concentrations ranging from 0.42 to $21.81 \mathrm{wt} . \%$, with an average $(n=70)$ of 12.09 wt. \% (Figs 5-6). This sphalerite is Fe-poor 


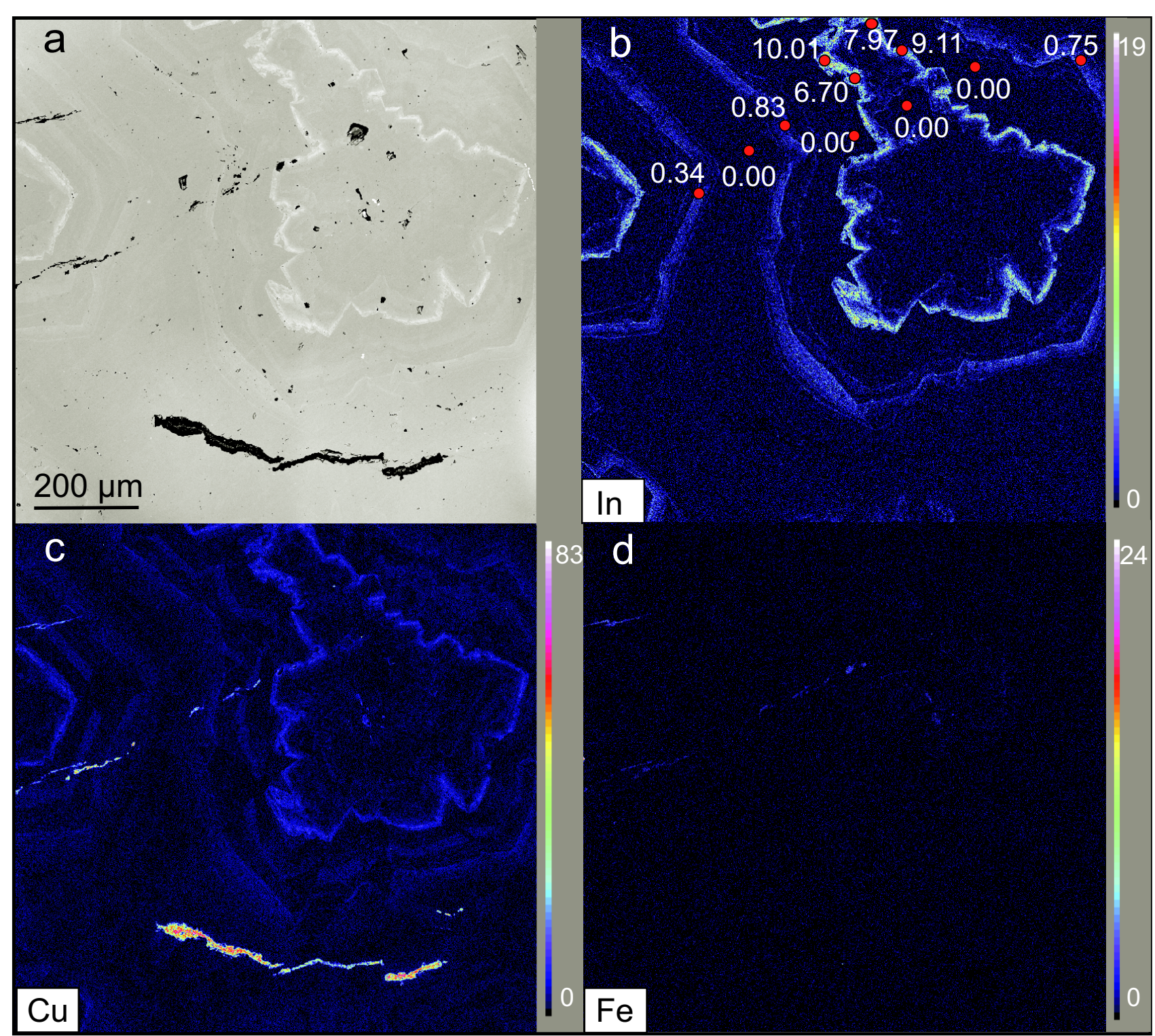

Fig. 4a - BSE image of zoned In-bearing sphalerite. $\mathbf{b}$ - WDS map of In in the section, numbers indicate the In concentration (in wt. \%) in sphalerite. $\mathbf{c}$ and $\mathbf{d}-$ WDS $\mathrm{Cu}$ and $\mathrm{Fe}$ map of the section, respectively.

(Tab. 1, Figs 4d, 5f) with less than 0.18 wt. \% Fe. Cadmium, Ga and $\mathrm{Sb}$, when present, have very low contents, with averages $(n=70)$ of $0.57,0.54$ and 0.11 wt. $\%$, respectively. All other analyzed elements (Ge, As, Se, $\mathrm{Ag}, \mathrm{Sn}, \mathrm{Te}, \mathrm{Au}, \mathrm{Pb}$ and $\mathrm{Bi}$ ) are systematically below their respective detection limits.

\subsection{Indium-bearing tennantite-(Zn)}

Indium-bearing tennantite-( $\mathrm{Zn})$ is scarce and its presence is restricted to the occurrence of ishiharaite. The concentration of indium in this mineral is up to 0.24 wt. $\%$ and gives an average value $(n=6)$ of 0.18 wt. $\%$. These figures contrast with those of tennantite-(Zn) or tennantite-(Fe) elsewhere in the deposit that systemati- cally yield indium contents below its detection limit (0.03 wt. \%). Unlike sphalerite, the presence of In does not alter the optical appearance of the mineral. It is consistent with the results presented by George et al. (2017), who concluded that partitioning of In into tennantite is poor. One analysis of tennantite-(Fe) and one of tennantite$(\mathrm{Zn})$ without indium and six analyses of indium-bearing tennantite-( $\mathrm{Zn})$ are given in Tab. 2.

\subsection{Ishiharaite}

Ishiharaite [(Cu, Ga,Fe,In,Zn)S ] was discovered in Capillitas, at the Nueva Esperanza vein (Márquez-Zavalía et al. 2014). Under the polarizing-reflected light microscope, ishiharaite is burgundy brown with a faint violet hue in 

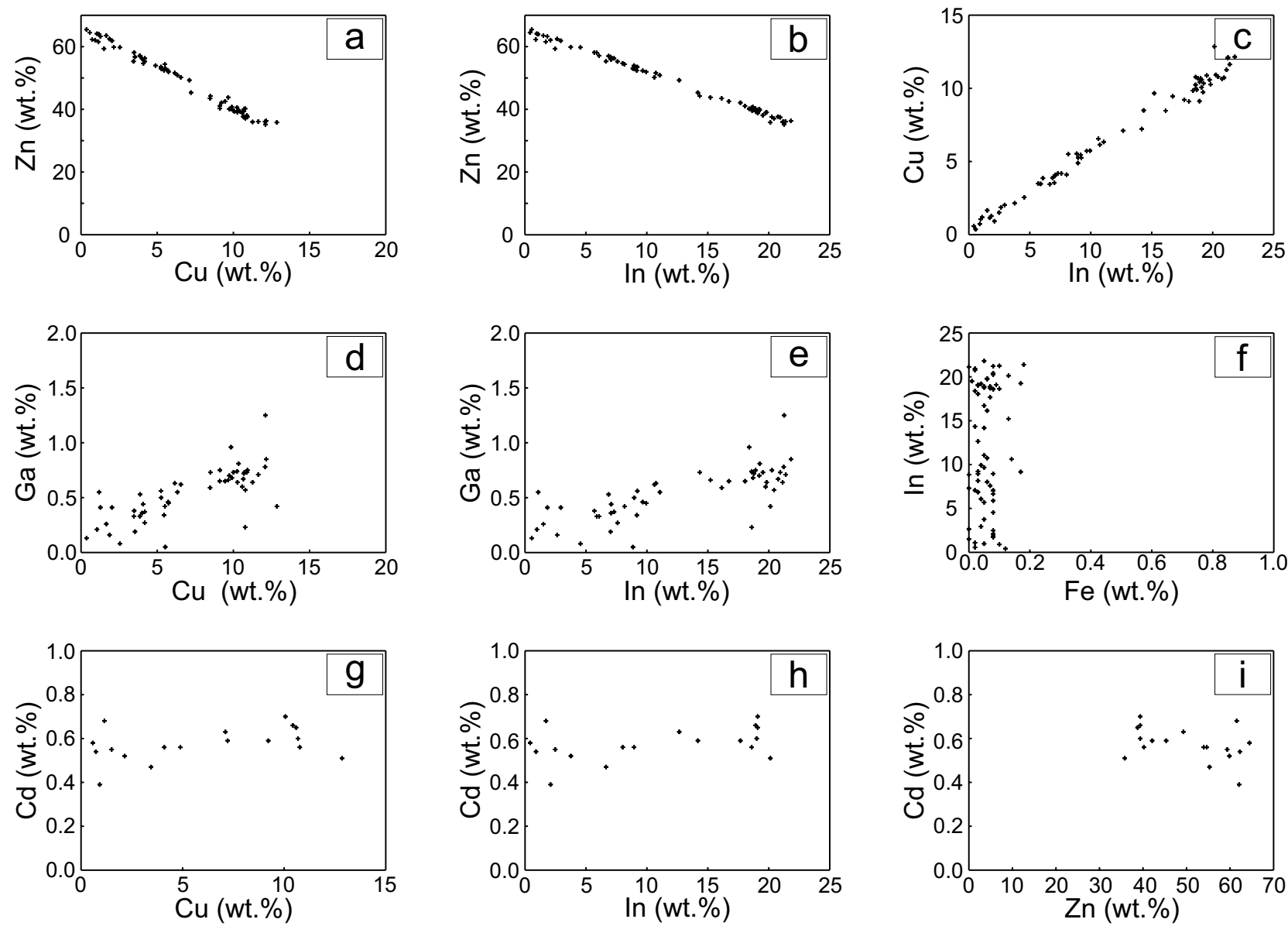

Fig. 5 Relationships between $\mathbf{a}-\mathrm{Cu}$ and $\mathrm{Zn}, \mathbf{b}-\mathrm{In}$ and $\mathrm{Zn}, \mathbf{c}-\mathrm{In}$ and $\mathrm{Cu}, \mathbf{d}-\mathrm{Cu}$ and $\mathrm{Ga}, \mathbf{e}-\mathrm{In}$ and $\mathrm{Ga}, \mathbf{f}-\mathrm{Fe}$ and $\mathrm{In}, \mathbf{g}-\mathrm{Cu}$ and $\mathrm{Cd}, \mathbf{h}-\mathrm{In}$ and $\mathrm{Cd}$ and $\mathbf{i}-\mathrm{Zn}$ and $\mathrm{Cd}$ derived from all the electron-microprobe analyses of the In-bearing sphalerite.

air and violet-burgundy in oil. This isotropic mineral occurs in subhedral, equidimensional, individual grains, up to $50 \mu \mathrm{m}$ in size, embedded in tennantite-(Zn) (Fig. 3c).
It is associated with sphalerite, pyrite, chalcopyrite and galena in a quartz gangue. Three representative analyses are given in Tab. 3 .

Tab. 1 Representative compositions of sphalerite, In-bearing sphalerite and an unknown In-bearing mineral from Nueva Esperanza and Restauradora veins (wt. \% and apfu)

\begin{tabular}{|c|c|c|c|c|c|c|c|c|}
\hline \multirow{2}{*}{$\begin{array}{l}\text { Mineral } \\
\text { Analysis }\end{array}$} & \multicolumn{2}{|c|}{ Sphalerite } & \multicolumn{5}{|c|}{ In-bearing sphalerite } & \multirow{2}{*}{$\begin{array}{c}\text { In-rich mineral } \\
\text { Average of } n=10\end{array}$} \\
\hline & Sp-01 & $\mathrm{Sp}-02$ & In-Sp-01 & In-Sp-03 & In-Sp-04 & In-Sp-05 & In-Sp-07 & \\
\hline $\bar{S}$ & 33.13 & 33.18 & 32.46 & 32.49 & 32.81 & 30.40 & 31.02 & 29.78 \\
\hline $\mathrm{Zn}$ & 66.11 & 66.38 & 63.21 & 60.09 & 54.66 & 43.82 & 39.37 & 31.43 \\
\hline $\mathrm{Cu}$ & 0.15 & 0.10 & 1.26 & 2.90 & 4.10 & 9.66 & 10.06 & 13.24 \\
\hline In & b.d.l. & 0.04 & 1.97 & 4.29 & 8.02 & 15.21 & 19.10 & 24.47 \\
\hline $\mathrm{Fe}$ & b.d.l. & 0.11 & b.d.l. & 0.17 & n.a. & 0.13 & n.a. & 0.09 \\
\hline Total & 99.39 & 99.80 & 98.90 & 99.93 & 100.14 & 99.23 & 100.24 & 99.55 \\
\hline $\mathrm{S}$ & 1.01 & 1.01 & 1.00 & 1.00 & 1.02 & 1.00 & 1.02 & 4.04 \\
\hline $\mathrm{Zn}$ & 0.99 & 0.99 & 0.96 & 0.91 & 0.84 & 0.70 & 0.63 & 2.09 \\
\hline $\mathrm{Cu}$ & 0.00 & 0.00 & 0.02 & 0.05 & 0.06 & 0.16 & 0.17 & 0.91 \\
\hline In & 0.00 & 0.00 & 0.02 & 0.04 & 0.07 & 0.14 & 0.18 & 0.93 \\
\hline $\mathrm{Fe}$ & 0.00 & 0.00 & 0.00 & 0.00 & - & 0.00 & - & 0.01 \\
\hline Total & 2.00 & 2.00 & 2.00 & 2.00 & 2.00 & 2.00 & 2.00 & 8.00 \\
\hline
\end{tabular}

b.d.1. - below detection limit; n.a. - not analyzed. 


\section{$\mathrm{Cu}$}

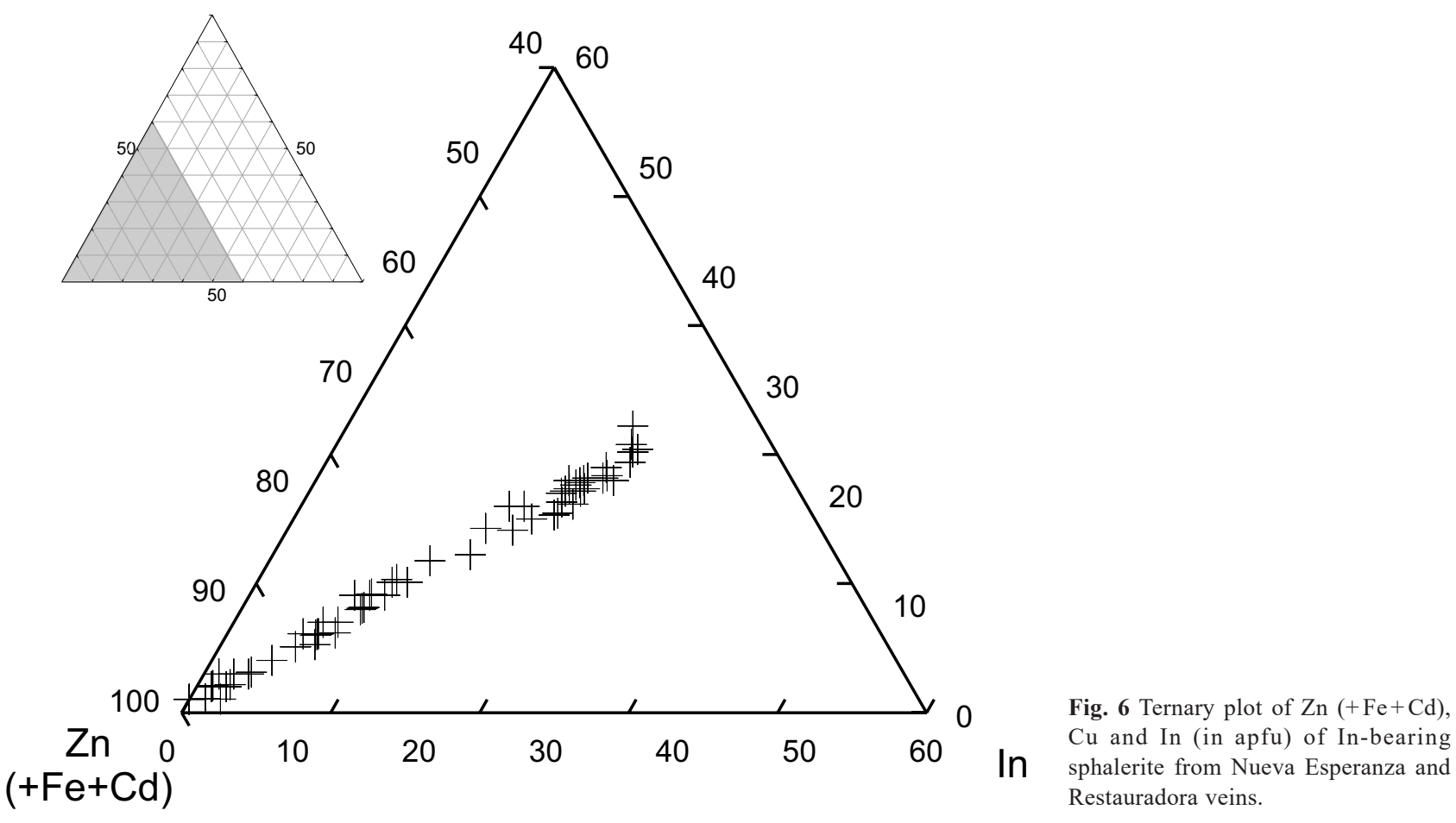

\subsection{Indium-bearing mineral}

During earlier stages of the research, ribbons of an undetermined mineral of light color were noticed within sphalerite in samples from the Nueva Esperanza and Restauradora veins. These ribbons are generally thinner than a few microns, reaching occasionally up to $15 \mu \mathrm{m}$
(Fig. 3d). This mineral is rich in indium, as well as some of the sphalerite grains that host the indium-bearing mineral, although it is noteworthy to say that other sphalerite crystals associated with this indium-bearing mineral are indium-free. In a few cases, in some areas of the zoned sphalerite crystals, and when the indium content in sphalerite exceeds $22 \mathrm{wt} . \%$, the zoning on sphalerite stops and

Tab. 2 Representative compositions of the three tennantite types [Tnt-(Fe), Tnt-(Zn) and In-bearing Tnt-(Zn)] from Nueva Esperanza and Restauradora veins (wt. \% and apfu)

\begin{tabular}{lcccccccc}
\hline Mineral & Tennantite-(Fe) & Tennantite-(Zn) & & \multicolumn{4}{c}{ In-bearing tennantite-(Zn) } \\
Analysis & Tnt-(Fe)-01 & Tnt-(Zn)-01 & In-Tnt-01 & In-Tnt-02 & In-Tnt-03 & In-Tnt-04 & In-Tnt-05 & In-Tnt-06 \\
\hline $\mathrm{S}$ & 27.24 & 25.69 & 27.70 & 26.80 & 26.23 & 26.15 & 26.16 & 26.88 \\
$\mathrm{As}$ & 20.14 & 9.45 & 14.66 & 12.15 & 12.97 & 12.12 & 11.90 & 13.24 \\
$\mathrm{Sb}$ & 1.32 & 6.42 & 7.02 & 5.99 & 2.30 & 4.28 & 2.76 & 5.66 \\
$\mathrm{Bi}$ & $\mathrm{b} . \mathrm{d} .1$. & 12.69 & 1.07 & 7.60 & 11.44 & 10.75 & 12.77 & 6.19 \\
$\mathrm{Cu}$ & 45.59 & 38.91 & 40.17 & 40.15 & 38.86 & 39.08 & 39.75 & 40.24 \\
$\mathrm{Zn}$ & 3.23 & 7.32 & 8.84 & 7.91 & 7.26 & 7.84 & 7.14 & 8.23 \\
$\mathrm{Fe}$ & 3.08 & 0.16 & 0.13 & 0.14 & 0.71 & 0.14 & 0.10 & 0.19 \\
$\mathrm{In}$ & b.d.1. & b.d.1. & 0.14 & 0.16 & 0.17 & 0.17 & 0.20 & 0.24 \\
\hline Total & 100.60 & 100.64 & 99.71 & 100.90 & 99.94 & 100.52 & 100.78 & 100.86 \\
\hline $\mathrm{S}$ & 12.63 & 12.80 & 13.23 & 12.83 & 13.17 & 13.12 & 13.17 & 13.10 \\
$\mathrm{As}$ & 4.00 & 2.01 & 3.00 & 2.49 & 2.79 & 2.60 & 2.56 & 2.76 \\
$\mathrm{Sb}$ & 0.16 & 0.84 & 0.88 & 0.75 & 0.30 & 0.57 & 0.37 & 0.73 \\
$\mathrm{Bi}$ & 0.00 & 0.97 & 0.08 & 0.56 & 0.88 & 0.83 & 0.99 & 0.46 \\
$\mathrm{Cu}$ & 10.66 & 10.54 & 9.68 & 10.45 & 9.84 & 9.89 & 10.10 & 9.90 \\
$\mathrm{Zn}$ & 0.73 & 1.79 & 2.07 & 1.86 & 1.79 & 1.93 & 1.76 & 1.97 \\
$\mathrm{Fe}$ & 0.82 & 0.04 & 0.03 & 0.04 & 0.20 & 0.04 & 0.03 & 0.05 \\
In & 0.00 & 0.00 & 0.02 & 0.02 & 0.02 & 0.02 & 0.03 & 0.03 \\
\hline Total & 29.00 & 29.00 & 29.00 & 29.00 & 29.00 & 29.00 & 29.00 & 29.00 \\
\hline
\end{tabular}

b.d.1. - below detection limit. 
this independent mineral phase precipitates with indium contents ranging from 22.07 to nearly $30 \mathrm{wt}$. \%, with an average $(n=20)$ of 24.47 wt. \%. Furthermore, this indium-bearing mineral is also present in other crystals of sphalerite with no indium content. Table 1 displays the average chemical composition of the indium-bearing mineral still under study. It seems that there is a solid solution between In-bearing sphalerite and this new unnamed indium-bearing mineral (Fig. 7). Similar cases have been reported by Ohta $(1980,1989)$ from Toyoha mine (Japan), Semenyak et al. (1994) from the Pravourmiiskoe deposit (Russia) and Sahlström et al. (2017a) from Mt. Carlton, Queensland (Australia). Murakami and Ishihara (2013) described an undetermined Zn-In mineral in Huari Huari (Bolivia), with an average Fe content of 12.79 wt. \%, different to the mineral described here, which is characterized by an average content of 0.06 wt. \% Fe.

\section{Discussion}

The studied sphalerite that formed during the third mineralization stage does not contain any indium, in contrast with the one grown later on during the fourth stage. This suggests either unfavorable physico-chemical conditions for indium precipitation or that there was not enough indium in the fluids. This is coincident with observations made by Bauer et al. (2019) that In is introduced relatively late in the epithermal system. But, unlike in their observations, there is no evidence that a richer Insphalerite was formed as a result of the decomposition (diffusion-induced segregation) of In-bearing chalcopyrite (not found in Capillitas), at the rims and along the fractures inside the sphalerite crystals. In Capillitas, indium richer areas in sphalerite are indeed towards the center of the grains.

The indium-bearing sphalerite crystals in these veins generally occur when they have small indium-free chalcopyrite inclusions or veinlets associated with them (chalcopyrite disease textures were not found). This was also observed in Mount Pleasant by Sinclair et al. (2006), and these authors ascribed the indium content in sphalerite to a possible diffusion as a result of a partial replacement of

Fig. 7 Binary plot In-Zn showing the compositions of In-bearing sphalerite and In-bearing mineral.
Tab. 3 Representative compositions of ishiharaite from Nueva Esperanza and Restauradora veins (wt. \% and apfu)

\begin{tabular}{lrrr}
\hline Mineral & \multicolumn{3}{c}{ Ishiharaite } \\
Analysis & Ish-01 & Ish-02 & Ish-03 \\
\hline $\mathrm{S}$ & 30.30 & 30.36 & 30.95 \\
$\mathrm{Sb}$ & $\mathrm{b} . \mathrm{d} .1$. & $\mathrm{b} . \mathrm{d} .1$. & 0.12 \\
$\mathrm{Zn}$ & 4.54 & 4.78 & 5.08 \\
$\mathrm{Cu}$ & 34.47 & 34.48 & 33.92 \\
$\mathrm{In}$ & 9.81 & 10.33 & 9.80 \\
$\mathrm{Ga}$ & 13.17 & 12.76 & 13.56 \\
$\mathrm{Fe}$ & 7.09 & 7.07 & 6.84 \\
$\mathrm{Ge}$ & $\mathrm{n} . \mathrm{a}$. & $\mathrm{n} . \mathrm{a}$. & 0.14 \\
\hline Total & 99.38 & 99.78 & 100.40 \\
\hline $\mathrm{S}$ & 0.97 & 0.97 & 0.97 \\
$\mathrm{Sb}$ & 0.00 & 0.00 & 0.00 \\
$\mathrm{Zn}$ & 0.07 & 0.07 & 0.08 \\
$\mathrm{Cu}$ & 0.55 & 0.55 & 0.54 \\
$\mathrm{In}$ & 0.09 & 0.09 & 0.09 \\
$\mathrm{Ga}$ & 0.19 & 0.19 & 0.20 \\
$\mathrm{Fe}$ & 0.13 & 0.13 & 0.12 \\
$\mathrm{Ge}$ & - & - & 0.00 \\
\hline Total & 2.00 & 2.00 & 2.00 \\
\hline $\mathrm{b} . \mathrm{d}-\mathrm{r}$
\end{tabular}

b.d.1. - below detection limit; n.a. - not analyzed.

sphalerite by chalcopyrite. Since the latter was not able to incorporate in its structure the indium present in the replaced sphalerite, indium was concentrated in the surrounding areas of the replacement. Cook et al. (2011a) also noted that chalcopyrite incorporates indium in its structure only when sphalerite plays a negligible role in the paragenesis. Indeed, this is not the case of the Nueva Esperanza and Restauradora veins, where sphalerite is abundant and the chalcopyrite crystals analyzed do not

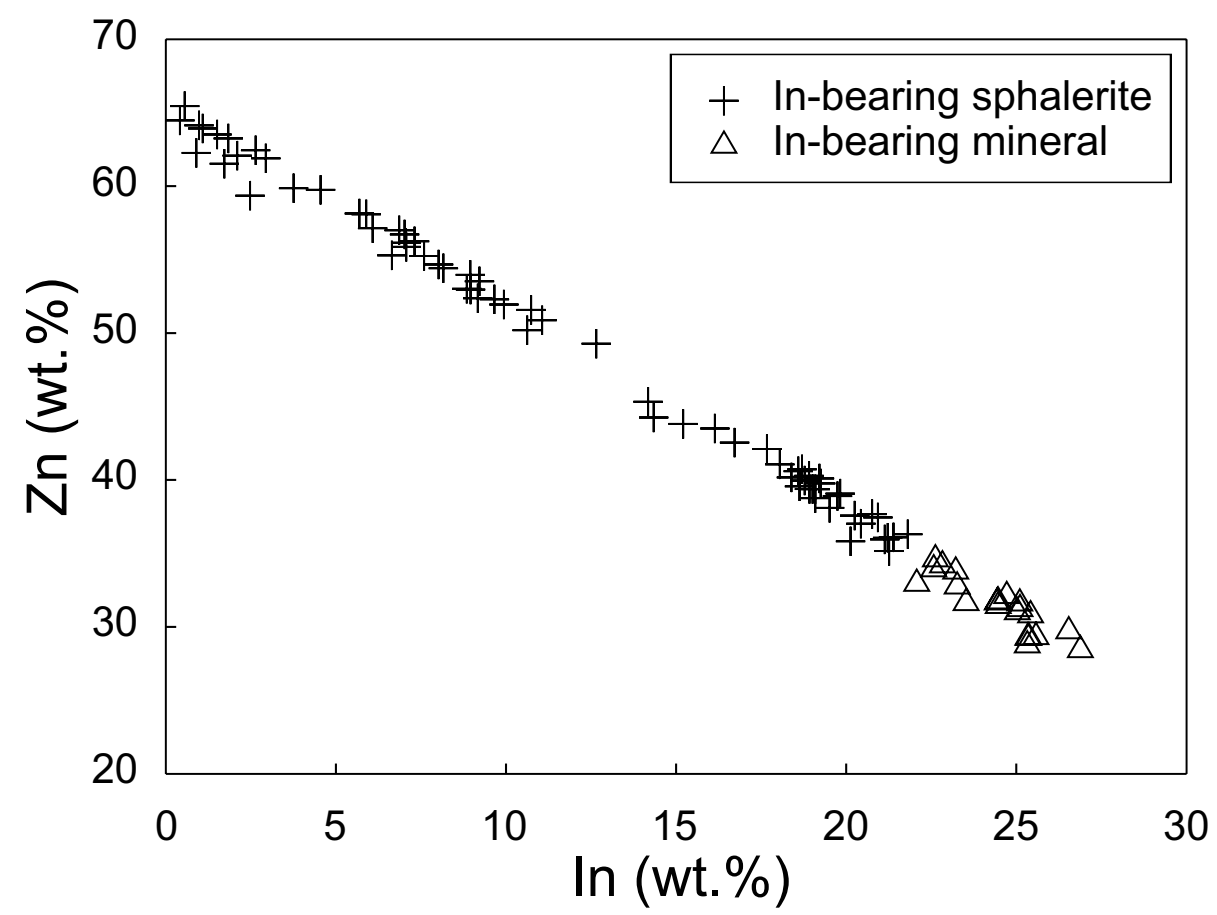


contain any In above the detection limit (0.03 wt. \%) of the electron-microprobe analyses.

To our best knowledge, sphalerite crystals investigated in the current study are the richest in indium ever found. They are closely followed by the indium-rich sphalerite (up to 19.59 wt. \% In) described in Mt. Carlton, Queensland, Australia (Sahlström et al. 2017a).

The indium-bearing sphalerite described here also bears some differences (Figs 5-6) from most other indium-bearing sphalerites (e.g., Pattrick et al. 1993; Sinclair et al. 2006; Cook et al. 2009; López et al. 2015). Sphalerite from Mt. Pleasant, New Brunswick, Canada (Sinclair et al. 2006) has higher content of Fe (up to 12 wt. \%) and its In: Cu ratio varies from close to $1: 1$ to almost 1:7 apfu. Sphalerite from Pasco, Perú (Benites et al. 2019) and Huari Huari, Bolivia (Torró et al. 2019a) are also systematically rich in Fe.

Sphalerite from Capillitas is also different from the sphalerite described at the Pravourmiiskoe deposit, Russia (Semenyak et al. 1994), which has lower contents of In (up to 2.4 wt. $\%$ In) while $\mathrm{Fe}$ and $\mathrm{Cd}$ are present (up to 2.3 and 1.1 wt. \%, respectively). Sphalerite described at Huari Huari district, Bolivia (Torró et al. 2019a) reaches In concentrations up to 3.49 wt. \%; similar data were presented by Murakami and Ishihara (2013). Torró et al. (2019a) reported an average concentration of $0.50 \mathrm{wt} \%$ In in sphalerite of the Ánimas-Chocaya-Siete Suyos district, Bolivia.

Frequently, the high concentrations of indium occur in deposits where tin is abundant and widely represented (e.g., Oen et al. 1980; Ohta 1989; Guido et al. 2005; Sinclair et al. 2006; Zhang et al. 2006; Cook et al. 2011b; Torró et al. 2019a, b; Benites et al. 2019). However, in the Nueva Esperanza and Restauradora veins, the only Sn minerals (stannite, stannoidite and mawsonite) are extremely scarce. Their contents of indium are below the detection limit, and they generally do not occur in the vicinity of the indium-bearing paragenesis.

At the Toyoha mine, Hokkaido, Japan, the highest indium concentration reported for sphalerite by Ohta (1989) is close to 9 wt. \%, and the contents of $\mathrm{Cu}, \mathrm{Fe}, \mathrm{Sn}$ and $\mathrm{Cd}$ are up to $7.5,7.2,1.7$ and 0.7 wt. \%, respectively, with an In: $\mathrm{Cu}$ ratio close to $1: 1$. Sphalerite from the Capillitas veins is richer in indium despite having similar contents of $\mathrm{Cu}$ and $\mathrm{Cd}$, but negligible amounts of $\mathrm{Fe}$ and no $\mathrm{Sn}$. The indium-bearing sphalerite from Långban, Bergslagen, Sweden (Burke and Kieft 1980) contains up to 10 wt. \% of In, and the rims of the crystals of sphalerite have higher concentrations of this element, just the opposite than in the indium-bearing sphalerite samples described in this contribution (Fig. 4b). Seifert and Sandmann (2006) gave a vast list of indium concentrations in sphalerites, as well as in other minerals and bulk-ore samples from deposits worldwide, which does not show any sphalerite with contents over 10 wt. \% In, except for a single analysis on sphalerite from a basaltic andesite of an active magmatic system (Kudryavyi volcano, Kuril Island Arc, Russia) reaching 14.9 wt. \% In, with an average of 5.9 wt. \%. Cook et al. (2009) reported indium contents in sphalerites from several deposits located in the Golden Quadrilateral district, Romania, and also from Toyoha mine, Japan, with values ranging from 1 to $669 \mathrm{ppm}$ In for the former and up to $58,752 \mathrm{ppm}$ In for the latter.

Indium in the studied sphalerite crystals (Tab. 1; Figs 5-7), as the example shown in Fig. 4b, shows a tendency to reach higher concentrations in the inner to intermediate parts of the crystals. The indium contents tend to decrease, along with alternating indium-rich and indiumfree bands, towards the rims. They indicate a generally diminishing concentration of indium in the mineralizing fluids as they evolved. A similar observation was reported from the Izumo vein of the Toyoha mine (Ohta 1989; Shimizu and Morrishita 2012).

From the mineral assemblage and the homogenization temperature of fluid inclusions (Márquez-Zavalía 1988; Márquez-Zavalía and Craig 2004), we infer that the $\log f \mathrm{~S}_{2}$ values evolved from the initial stages with relics of pyrrhotite, pyrite ( \pm arsenopyrite) to the later stages with pyrite, chalcopyrite and sphalerite instead of pyrrhotite, when the fluids deposited the In-bearing minerals. We deduce that the $\mathrm{pH}$ of the hydrothermal fluids increased, due to the absolute dominance of quartz over rhodochrosite, until the third stage of the mineralization. During subsequent stages it was followed by a gradual increase of rhodochrosite occurrence, especially in other veins at the deposit; this $\mathrm{pH}$ change was accompanied by a gradual cooling of the fluids (Márquez-Zavalía 1988; Márquez-Zavalía and Craig 2004). Physico-chemical conditions favorable for the substitution of $\mathrm{Zn}$ for $\mathrm{In}-\mathrm{Cu}$ (Schwarz-Schampera and Herzig 2002) concur with the microthermometrical data and the position of the indium-bearing sphalerite in the paragenetic sequence of this deposit. As the $\mathrm{In}: \mathrm{Cu}$ ratio is consistently close to $1: 1$, we agree with Johan (1988), Cook et al. (2012) and Sahlström et al. (2017a, b) that $\mathrm{Cu}^{+}$is the main cation involved in the coupled substitution $2 \mathrm{Zn}^{2+} \leftrightarrow \mathrm{Cu}^{+}+\mathrm{In}^{+}$.

In the Capillitas veins, it was assumed that the fluids suffered from significant fluctuation in their composition (possibly pulses) during the fourth stage of the mineralization, as it is evidenced by the presence of both, a high $f \mathrm{Te}_{2}$ phase like calaverite and a low $f \mathrm{Te}_{2}$ one as silver (Márquez-Zavalía and Craig 2004). Accordingly, zoning in sphalerite could be ascribed to changes in the physical chemistry of the mineralizing fluids with local periodic increments on $\mathrm{In}$ and $\mathrm{Cu}$ that were associated with recurring reactivation of fractures, as has been suggested already (Sibson 1981; Pattrick et al. 1993). 
Indium, among other chalcophile elements, might be sourced from a low- to intermediate-salinity fluid (e.g., Heinrich 2005), coming from an associated porphyry intrusion in the Farallón Negro Volcanic Complex (e.g., Sillitoe 1973, 1996; Márquez-Zavalía and Heinrich 2016, and references therein).

\section{Conclusions}

1. Sphalerite from the Nueva Esperanza and Restauradora veins is the richest known in indium among sphalerites from epithermal deposits. It keeps in its structure up to 22 wt. \% of In. Whenever that amount is surpassed, a new phase, still under study by the authors, began to crystallize, not as bands but as irregular ribbon-like inclusions with indium concentrations from 22 wt. \% to close to 30 wt. $\%$.

2. Taking into account the constant $\mathrm{In}: \mathrm{Cu}$ ratio close to $1: 1$, we identify $\mathrm{Cu}^{+}$as the principal cation involved in the incorporation of In in the structure of sphalerite through a $2 \mathrm{Zn}^{2+} \leftrightarrow \mathrm{Cu}^{+}+\mathrm{In}^{+}$coupled substitution.

3. Cadmium reaches values up to 0.68 wt. $\%$ while $\mathrm{Fe}$ is almost absent from the structure of sphalerite (up to 0.19 wt. \%).

4. Unlike most deposits, In-bearing sphalerite from the studied veins is not associated with minerals of the Sn-rich paragenesis.

5. Exploration for indium in Argentina should be encouraged. It would be highly advisable to re-study the main zinc deposits, looking for the presence of this critical element, which in previous studies, may have been overlooked.

Acknowledgments. This study was made possible by the Argentinean support of CONICET through PIP 11220120100554-CO grant. This is a contribution to the Strategic Research Plan of the Czech Geological Survey (DKRVO/ČGS 2018-2022). The authors are grateful to Petr Černý for microprobe access at the University of Manitoba; they are also very grateful for the constructive reviews of Panagiotis Voudouris and Lisard Torró. The editorial handling and comments of the Editor Jiří Zachariáš and the Editors-in-Chief Jakub Plášil and Vojtěch Janoušek are much appreciated.

\section{References}

Anders E, Grevesse N (1989) Abundances of elements: meteoritic and solar. Geochim Cosmochim Acta 53: 197-214

Armstrong JT (1993) Caltech 1993 JEOL license of CITZAF, version 3.5
Bauer ME, Seifert T, Burisch M, Krause J, Richter N, GutZmer J (2019) Indium-bearing sulfides from the Hämmerlein skarn deposit, Erzgebirge, Germany: evidence for late-stage diffusion of indium into sphalerite. Miner Depos 54:175-192

Benites D, Torró L, Vallance J, Quispe P, Sáez J, Rosas S, Fernández-Baca A, Gamarra J, Camprubí A, Fontвoté L (2019) Ore mineralogy of the In-bearing Ayawilca $\mathrm{Zn}-\mathrm{Ag}-\mathrm{Sn}-\mathrm{Cu}$ project, Pasco, Peru. In: Life with Ore Deposits on Earth, vol. 4. Proceedings of the $15^{\text {th }}$ Biennial SGA Meeting, Glasgow, pp 1681-1684

Bindi L, Putz H, PaAr WH, Stanley CJ (2017) Omariniite, $\mathrm{Cu}_{8} \mathrm{Fe}_{2} \mathrm{ZnGe}_{2} \mathrm{~S}_{12}$, the germanium-analogue of stannoidite, a new mineral species from Capillitas, Argentina. Mineral Mag 81: 1151-1159

BuRKe EAJ, Kieft C (1980) Roquesite and Cu-In-bearing sphalerite from Långban, Bergslagen, Sweden. Canad Mineral 18: 361-363

Cook nJ, Ciobanu CL, Pring A, Skinner W, DanyuShevsky L, Shimizu M, Saini-Eidukat B, Melcher F (2009) Trace and minor elements in sphalerite: a LA-ICPMS study. Geochim Cosmochim Acta 73: 4761-4791

Cook nu Ciobanu CL, Danyushevsky LV, Gilbert S (2011a) Minor and trace elements in bornite and associated $\mathrm{Cu}-(\mathrm{Fe})$-sulphides: A LA-ICP-MS study. Geochim Cosmochim Acta 75: 6473-6496

Cook NJ, Sundblad K, Valkama M, Nygård R, Ciobanu CL, DANYUSHEVSKY L (2011b) Indium mineralisation in A-type granites in southeastern Finland: insights into mineralogy and partitioning between coexisting minerals. Chem Geol 284: 62-73

Cook nJ, Ciobanu CL, Brugger J, Etschmann B, Howard DL, de Jonge MD, Ryan C, Paterson D (2012) Determination of the oxidation state of $\mathrm{Cu}$ in substituted $\mathrm{Cu}-\mathrm{In}-\mathrm{Fe}$-bearing sphalerite via $\mu$-XANES spectroscopy. Amer Miner 97: 476-479

EfFenberger H, Lengauer CL, Libowitzky E, Putz H, Topa D (2015) Lislkirchnerite, IMA 2015-064. CNMNC Newsletter No. 27, October 2015, page 1230. Mineral Mag 79: 1229-1236

Gallard-Esquivel C, Cepedal A, Fuertes-Fuente M, MARTIN-IZARD A (2018) Enrichment in critical metals (In-Ge) and Te-Se in epithermal deposits of the ' $\mathrm{La}$ Carolina' district, San Luis, Argentina. Mineral Mag 82: S61-S87

George L, Cook N, Ciobanu C (2017) Minor and trace elements in natural tetrahedrite-tennantite: effects on element partitioning among base metal sulphides. Minerals 7: $17-42$

Gómez C, Luna L, Garrido M, Bonuccelli R (2008) Manifestación de indio en el Macizo Nordpatagónico: proyecto San Roque, provincia de Rio Negro. In: $9^{\circ}$ Congreso de Mineralogía y Metalogenia, San Salvador de Jujuy, pp 125-128 
Goonan TG (2012) Materials flow of indium in the United States in 2008 and 2009. U.S. Geological Survey Circular 1377: pp 1-12, available at http://pubs.usgs.gov/ circ/1377

Guido D, Jovic S, Schalamuk I (2005) A new metallogenic association ( $\mathrm{Sn}-\mathrm{Cd}-\mathrm{In}-\mathrm{Zn}-\mathrm{Ag}-\mathrm{Au})$ in the Deseado Auroargentiferous Province, Deseado Massif, Patagonia, Argentina. Mineral Deposit Research 2: 965-968

HeINRICH CA (2005) The physical and chemical evolution of low-salinity magmatic fluids at the porphyry to epithermal transition: a thermodynamic study. Miner Depos 39: 864-889

JICA (Japan International Cooperation Agency) (19781981) Informe de estudios básicos sobre la explotación de recursos minerales en la zona norte de la República Argentina. Cuatro etapas. Dirección General de Fabricaciones Militares, informe inédito, Buenos Aires, pp $1-520$

JOHAN Z (1988) Indium and germanium in the structure of sphalerite: an example of coupled substitution with copper. Mineral Petrol 39: 211-229

Jovic SM (2009) Geología y metalogénesis de las mineralizaciones polimetálicas del área El Tranquilo (Cerro León), sector central del macizo del Deseado, Provincia de Santa Cruz. Unpublished Ph.D. thesis, National University of La Plata, La Plata, pp 1-278

Jovic SM, Guido DM, Melgarejo JC, PÁez GN, Ruiz R, ScHALAMUK IB (2011) The indium-bearing minerals of the Pingüino polymetallic vein system, Deseado Massif, Patagonia, Argentina. Canad Mineral 49: 931-946

Jovic SM, López L, Guido D, Redigonda J, PÁEz G, Ruiz R, Pemuy Vidal C (2015) Presencia de indio en sistemas epitermales polimetálicos de Patagonia. Rev Asoc Geol Argent 71: 433-437

López L, Jovic S, Guido D, Páez G, Ruiz R, Permuy ViDAL C (2015) Geochemical distribution and supergene behavior of indium at the Pingüino epithermal polymetallic vein system, Patagonia, Argentina. Ore Geol Rev 64: 747-755

MÁrqueZ-ZaVAlía MF (1988) Mineralogía y génesis del yacimiento Capillitas (Catamarca, República Argentina). Unpublished Ph.D. thesis, National University of Salta, Salta, pp 1-258

MÁrQueZ-ZaVAlíA MF (1999) El yacimiento Capillitas, provincia de Catamarca. In: ZAPPETTINI EO (ed) Yacimientos Minerales de la República Argentina. Instituto de Geología y Recursos Minerales SEGEMAR, Buenos Aires, Anales 35, pp 1643-1652

MárQuez ZaVALÍA MF (2005) Indium minerals from Capillitas mine, northwestern Argentina. In: Gordon Research Conference on Inorganic Geochemistry: Metals in Ore-forming Systems: Sources, Transport, Deposition. Unpublished abstract, Proctor Academy, Andover, New Hampshire, USA
MÁrquez-Zavalía MF (2008) La rodocrosita de Mina Capillitas "Piedra" nacional Argentina - Rosa del Inca. In: Zappettini EO (ed) Sitios de Interés Geológico de la República Argentina. Editorial CSIGA. Instituto de Geología y Recursos Minerales, Servicio Geológico Minero Argentino - SEGEMAR, Buenos Aires, Anales 46, 85-98

Márquez-ZaValía MF, Craig JR (2004) Tellurium and precious metal mineralization at Mina Capillitas, northwestern Argentina. Neu Jb Mineral, Mh 2004(4): 176-192

MárqueZ-Zavalía MF, Heinrich CA (2016) Fluid evolution in a volcanic-hosted epithermal carbonate-basemetal-gold vein system: Alto de la Blenda, Farallón Negro, Argentina. Miner Depos 51: 873-902

Márquez-Zavalía M F, Galliski M A, DrábeK $M$, Vymazaloví A, Watanabe Y, Murakami H, BernhardT H-J (2014) Ishiharaite, (Cu, Ga, Fe, In, Zn)S, a new mineral from Capillitas mine, northwestern Argentina. Canad Mineral 52: 969-980

MuraKami H, IshiHara S (2013) Trace elements of indiumbearing sphalerite from tin-polymetallic deposits in Bolivia, China and Japan: a femto-second LA-ICPMS study. Ore Geol Rev 53: 223-243

Oen IS, Kager P, Kieft C (1980) Oscillatory zoning of a discontinuous solid-solution series sphalerite-stannite. Amer Miner 65: 1220-1232

OнтA E (1980) Mineralization of Izumo and Sorachi veins of the Toyoha mine, Hokkaido, Japan. Bull Geol Surv Japan 31: 99-113 (in Japanese with English abstract)

Oнта E (1989) Occurrence and chemistry of indiumcontaining minerals from the Toyoha mine, Hokkaido, Japan. Min Geol 41: 279-295

PaAr WH, de Brodtkorb MK, Sureda RJ, Topa D (1998) A microprobe study of complex Ag-Sn ores from Pirquitas, Jujuy province, Argentina. Abstracts for the Plenary Lectures, Symposia, and Special Sessions of the $17^{\text {th }}$ General Meeting of the International Mineralogical Association, Toronto, 1998, p A118

Paar WH, Roberts AC, Berlepsch P, Armbruster T, Topa D, Zagler G (2004) Putzite, $\left(\mathrm{Cu}_{4.7} \mathrm{Ag}_{3.3}\right)_{8} \mathrm{GeS}_{6}$, a new mineral species from Capillitas, Catamarca, Argentina: description and crystal structure. Canad Mineral 42: 1757-1769

PATtrick RAD, Dorung M, Polya DA (1993) TEM study of indium- and copper-bearing growth-banded sphalerite. Canad Mineral 31: 105-117

Pouchou JL, Pichoir F (1985) PAP $(\phi \rho Z)$ correction procedure for improved quantitative microanalysis. In: Armstrong JT (ed) Microbeam Analysis. San Francisco Press, San Francisco, pp 104-106

Putz H, Paar WH, Topa D, Makovicky E, Roberts AC (2006) Catamarcaite, $\mathrm{Cu}_{6} \mathrm{GeWS}_{8}$, a new species of germanium-tungsten sulfide from Capillitas, Catamarca, Argentina: description, paragenesis and crystal structure. Canad Mineral 44: 1481-1497 
Putz H, PaAr WH, Topa D (2009) A contribution to the knowledge of the mineralization at mina Capillitas, Catamarca. Rev Asoc Geol Argent 64: 514-524

Reich F, Richter HT (1863a) Vorläufige Notiz über ein neues Metall. J Prakt Chem 89: 441

Reich F, Richter HT (1863b) Über das Indium. J Prakt Chem 90: 172-176

Royal Society of Chemistry (2020) Indium. Accessed on May 1, 2020, at http://www.rsc.org/periodic-table/ element/49/indium

Sahlström F, Blake K, Corral I, Chang Z (2017a) Hyperspectral cathodoluminescence study of indium-bearing sphalerite from the Mt Carlton high-sulphidation epithermal deposit, Queensland, Australia. Eur J Mineral 29: 985-993

Sahlström F, Arribas A, Dirks P, Corral I, Chang Z (2017b) Mineralogical distribution of germanium, gallium and indium at the Mt. Carlton high-sulfidation epithermal deposit, NE Australia, and comparison with similar deposits worldwide. Minerals 7: 213-240

Schalamuk I, de Barrio R, Zubia M, Genini A, EcheVeste H (1999) Provincia Auroargentífera del Deseado, Santa Cruz. In: Zappettini EO (ed) Yacimientos Minerales de la República Argentina. Instituto de Geología y Recursos Minerales SEGEMAR, Buenos Aires, Anales 35, pp 1177-1188

Schwarz-Schampera U, HerzIG PM (2002) Indium. Geology, Mineralogy and Economics. Springer-Verlag, Berlin, Heidelberg, pp 1-257

SEIFERT T, SANDMANN D (2006) Mineralogy and geochemistry of indium-bearing polymetallic vein-type deposits: implications for host minerals from the Freiberg district, eastern Erzgebirge, Germany. Ore Geol Rev 28: 1-31

SEmenyak BI, NedAshKovskiI AP, Nikulin NN (1994) Indium minerals in the ores of the Pravourmiiskoe deposit (Russian Far East). Geol Ore Depos 36: 207-213

Shimizu T, Morishita Y (2012) Petrography, chemistry, and near-infrared microthermometry of indium-bearing sphalerite from the Toyoha polymetallic deposit, Japan. Econ Geol 107: 723-735
SIBSON RH, (1981) Fluid flow accompanying faulting: field evidence and models. In: SIMPSON DH, RichaRDS PO (eds) Earthquake Prediction: an International Review. American Geophysical Union, Maurice Ewing Series 4: 593-603

Sillitoe RH (1973) The tops and bottoms of porphyry copper deposits. Econ Geol 68: 799-815

Sillitoe RH (1996) Granites and metal deposits. Episodes 19: $126-133$

Sinclair WD, Kooiman GJA, Martin DA, KJarsgaArd IM (2006) Geology, geochemistry and mineralogy of indium resources at Mount Pleasant, New Brunswick, Canada. Ore Geol Rev 28: 123-145

TAYLOR SR, McLEnNAN SM (1985) The Continental Crust: Its Composition and Evolution. Blackwell, Oxford, pp 1-312

Torró L, Melgarejo JC, Gemmrich L, Mollinedo D, Cazorla M, Martínez A, Pujol-Solà N, Farréde-Pablo J, Camprubí A, Artiaga D, Torres B, Alfonso P, Arce O (2019a) Spatial and temporal control on the distribution of indium in xenothermal vein-deposits: the Huari Huari district, Potosí, Bolivia. Minerals 9: 304

Torró L, Cazorla M, Melgarejo JC, Camprubí A, Tarrés M, Gemmrich L, Campeny M, Artiaga D, Torres B, Martínez A, Mollinedo Alfonso P, Arce-BurgoA OR (2019b) Indium mineralization in the volcanic domehosted Ánimas-Chocaya-Siete Suyos polymetallic deposit, Potosí, Bolivia. Minerals 9: 604

Whitney DL, Evans BW (2010) Abbreviations for names of rock-forming minerals. Amer Miner 95: 185-187

Zappettini EO, de BrodtKorb MK, Godeas M, BernHARDT H-J (2004) Presencia de esfalerita rica en indio en el yacimiento El Peladar; provincia de Jujuy. In: $7^{\circ}$ Congreso de Mineralogía y Metalogénesis, Río Cuarto, Córdoba, pp 131-132

Zhang Q, Zhu X, He Y, Jiang J, Wang D (2006) Indium enrichment in the Meng'entaolegai Ag- $\mathrm{Pb}-\mathrm{Zn}$ deposit, Inner Mongolia, China. Resour Geol 56: 337-346 